\title{
PENGELOLAAN RESIKO YANG MEMPENGARUHI KINERJA MUTU PADA PELAKSANAAN PROYEK JALAN CIAMIS - BANJAR - PANGANDARAN - BATAS JATENG
}

\author{
Suryadharma Nyoman \\ Magister Teknik Sipil Universitas Sangga Buana \\ Email: suryadharmanyoman@yahoo.co.id
}

\begin{abstract}
ABSTRAK
Jalan merupakan bagian insfrastruktur yang berperan penting dalam sistim transportasi nasional. sebagai Aktifitas ekonomi, baik pada perkotaan maupun pada daerah, dan pengembangan wilayah membutuhkan pembangunan jalan pendukung utama. Didalam pelaksanaan proyek pekerjaan jalan dengan jenis perkerasan lentur di Provinsi Jawa Barat menurut data pelaksanaan proyek, baik pada masa pelaksanaan maupun pada masa pemeliharaan, banyak terjadi perbaikan hasil pekerjaan. Hal ini menggambarkan kurang baiknya kinerja mutu pelaksanaan proyek. Tujuan penelitian ini untuk mengetahui faktor resiko dominan penyebab rendahnya kinerja mutu proyek jalan. Penelitian ini menggunakan pendekatan kuantitatif dengan analisis data penelitian menggunakan Analysis Hierarchy Proses. Hasil pengumpulan data penelitian ini menggunakan kuesioner yang disebarkan kepada 56 responden, menunjukkan bahwa peristiwa resiko yang masuk dalam kategori tinggi pada pelaksanaan proyek jalan di Jalan Ciamis - Banjar - Pengandaran - Batas Jateng antara lain, material yang digunakan tidak sesuai spesifikasi, kualitas tim engineering proyek kurang baik, kompetensi personil tidak sesuai dengan tugas, tidak memperhatikan faktor resiko pada lokasi dan konstruksi, kedisiplinan tenaga kerja buruknya komunikasi dan koordinasi antar organisasi kerja, komunikasi yang kurang baik antar pihak yang terlibat, kurang komitmen dalam hal Quality Assurance dan Quality Control, kesalahan desain, dan penjadwalan proyek yang ketat.
\end{abstract}

Kata Kunci: resiko, proyek, kinerja mutu, jalan

\section{PENDAHULUAN}

Peruntukannya jalan terbagi atas jalan umum untuk lalu lintas umum dan jalan khusus untuk bukan lalu lintas umum. Jalan umum mencakup sistim jaringan jalan primer dan sekunder yang berdasarkan fungsinya dikelompokkan atas jalan arteri, jalan kolektor, jalan lokal dan jalan lingkungan. Sedangkan sesuai statusnya jalan di kelompokkan atas jalan nasional, jalan propinsi, jalan kabupaten, jalan kota dan jalan desa.

Menurut undang-undang nomor 38 tahun 2004 pengertian jalan adalah prasarana transportasi darat yang meliputi segala bagian jalan, termasuk bagian pelengkap dan perlengkapan yang diperuntukkan bagi lalu lintas, yang berada pada permukaan tanah, dibawah permukaan tanah dan atau air, serta di atas permukaan air kecuali jalan kereta api, jalan lori dan jalan kabel.

Jalan merupakan bagian insfrastruktur mempunyai peran yang penting dalam sistim transportasi nasional, menurut Dirjen Binamarga, dengan melayani 92\% angkutan penumpang dan $90 \%$ angkutan barang pada jaringan jalan yang ada. Manfaat strategis jalan menciptakan multiplier effect bagi perekonomian 
nasional antara lain menciptakan lapangan pekerjaan berskala besar, peningkatan sumber daya dalam negeri serta meningkatkan sektor riil.

Pembangunan jalan merupakan hal yang sangat dibutuhkan sebagai pendukung utama dalam aktifitas ekonomi, baik yang terletak pada perkotaan maupun pada daerah, dan pengembangan wilayah. Data Ditjen Bina Marga Kementerian PUPR menunjukkan panjang jalan nasional, yang semula sekitar $38.500 \mathrm{~km}$ menjadi sekitar $46.000 \mathrm{~km}$ dengan alokasi RPJMN 20152019 adalah Rp 278 triliun, yaitu konstruksi jalan bebas hambatan $1000 \mathrm{~km}$, pemeliharaan jalan nasional $45.592 \mathrm{~km}$, pembangunan flyover dan underpass pada perlintasan kereta api dan kota metropolitan 15000 meter, dukungan jalan sub-nasional $500 \mathrm{~km}$ dan pembangunan jalan nasional $2.650 \mathrm{~km}$. Pembangunan insfrastruktur jalan Indonesia menunjukkan perkembangan dalam kurun waktu periode 2015-2019 yang akan datang. Untuk memenuhi kebutuhan tersebut pemerintah maupun investor swasta giat mengadakan proyek pembangunan jalan baru dan juga proyek pengembangan jalan yang sudah ada.

Seperti disebutkan diatas bahwa jalan merupakan pendukung utama didalam pembangunan, maka mutu dari pada jalan tersebut harus baik agar kendaraan yang melintas diatasnya aman dan nyaman.
Akan tetapi pada kenyataannya banyak ditemukan mutu hasil pekerjaan jalan yang tidak sesuai dengan apa yang disyaratkan, sehingga berdampak kerusakan-kerusakan penanganan jaringan jalan nasional dan propinsi tidak terlepas dari kinerja mutu untuk mencapai kualitas perkerasan jalan yang mantap, banyak pernyataan yang didasarkan pada penglihatan semata bahwa kerusakan jalan semata-mata karena faktor pengaruh air dan beban kendaraan yang melebihi beban rencana, walaupun pengungkapannya tidak ditunjang data teknis yang akurat. Selama ini persoalan keterbatasan dana dan beban kendaraan berlebih (overloading) selalu dianggap penyebab utama kerusakan jalan. Kerusakan-kerusakan yang secara umur rencana seharusnya belum waktunya terjadi, dan juga pada saat proses pelaksanaan pekerjaan jalan (termasuk pada masa pemeliharaan) sering ditemukan ketidak sesuaian mutu sehingga mengakibatkan, kegagalan mutu perkerasan lentur dapat disebabkan oleh beberapa aspek yang berkaitan langsung dengan pengelolaan jalan, antara lain: (1) Kesalahan perencanaan terutama pemilihan mutu material yang kurang tepat dan kesalahan desain struktur perkerasan (Kasi, 1995; Wang, 2004; Aly, 2006); (2) Kesalahan pelaksanaan yang tidak sesuai dengan spesifikasi teknis (standar mutu) yang diterapkan (Mustazir, 1999; Paterson, 
1995 \& 2007.b; Bennett, 2000.a \& 2007.a; Morgan \& Casanova, 2006; Mulyono, 2006.b); (3) Kesalahan penulisan laporan administrasi proyek, terjadi ketidaksesuaian antara fakta lapangan dan laporan tertulis (Smith, 1996; Harris \& McCaffer, 2001; Mulyono, 2006.c); dan (4) ketidaktepatan pengendalian mutu, terjadi penyimpangan mutu terhadap standar mutu yang diimplementasikan (Bennett, 2004; Scott et al., 2004; Andriyanto, 2005; Soehartono, 2006.a).

Penyebab rendahnya kinerja mutu jalan perkerasan lentur adalah faktor tenaga kerja (labors), faktor bahan (material), faktor peralatan (equipment), faktor manajerial (managerial), faktor perencanaan. Hal ini berarti kinerja mutu sangat berpengaruh terhadap kinerja mutu perkerasan jalan. Oleh karena itu, secara praktis pengembangan spesifikasi teknis (standar mutu) perlu mencermati secara kritis permasalahan penerapannya di lapangan.

\section{TINJAUAN PUSTAKA}

\section{Manajemen Resiko}

Menurut Soemarmo (2007), pengertian resiko dalam konteks proyek dapat didefinisikan sebagai suatu penjabaran terhadap konsekuensi yang tidak menguntungkan, secara finansial maupun fisik, sebagai hasil dari keputusan yang diambil atau akibat kondisi lingkungan di lokasi suatu kegiatan. Definisi resiko adalah kemungkinan terjadinya sesuatu yang akan memberi dampak terhadap sasaran, diukur dalam konteks konsekuensi dan kemungkinan. Yang dimaksud dengan konsekuensi tersebut adalah hasil dari sebuah kejadian yang dinyatakan secara kualitatif atau kuantitatif, yang merupakan kehilangan, kerugian, atau keuntungan. Mungkin ada beragam hasil yang mungkin yang berhubungan dengan sebuah kejadian. Sedangkan kemungkinan adalah digunakan sebagai sebuah deskripsi kualitatif probabilitas atau frekuensi.

\section{Aspek-aspek Pelaksanaan Proyek Jalan}

\section{Aspek Material}

Manajemen material adalah pengelolaan; proses perencanaan, pengorganisasian, pelaksanaan, dan pengendalian. Manajemen Material atau Materials Management merupakan semua aktifitas yang dibutuhkan untuk mengatur aliran bahan baku (material) dari suplier melalui aktifitas sebuah sistem manajemen yang mengintegrasikan wilayah pembelian, memperlancar dan mengendalikan kemajuan dari vendor. Ini adalah bagian penting dari manajemen proyek dan biaya yang efektif

\section{Aspek Sumber Daya Manusia}

Sumber Daya Manusia (MSDM) merupakan bagian dari manajemen 
keorganisasian yang memfokuskan diri pada unsure sumber daya manusia. Adalah tugas manajemen sumber daya manusia untuk mengelola unsur manusia secara baik agar diperoleh tenaga kerja yang puas akan pekerjaannya.

Pengembangan sumber daya manusia ini dapat dilaksanakan melalui pendidikan dan pelatihan yang berkesinambungan. Pendidikan dan pelatihan merupakan upaya untuk pengembangaan SDM, terutama untuk pengembangan kemampuan intelektual dan kepribadian. Pendidikan pada umumnya berkaitan dengan mempersiapkan calon tenaga yang digunakan oleh suatu organisasi, sedangkan pelatihan lebih berkaitan dengan peningkatan kemampuan atau keterampilan pekerja yang sudah menduduki suatu jabatan atau tugas tertentu.

\section{Aspek Metode Pelaksanaan dan Peralatan Konstruksi}

Setiap proyek memiliki tujuan khusus, dimana masing-masing tujuan tersebut didalamnya terdapat batasan yang mendasar yaitu besarnya biaya yang dianggarkan, waktu yang dijadwalkan dan mutu yang harus dipenuhi. Ketiga batasan tersebut lebih dikenal dengan tiga kendala (triple constraint). Dari ketiga faktor tersebut saling terkait dan masing-masing memiliki hubungan saling ketergantungan, sehingga jika terjadi perubahan pada salah satu faktor tersebut maka akan mempengaruhi dua faktor yang lainnya.

\section{Aspek Lingkungan}

Setiap kegiatan pembangunan yang dilaksanakan pasti menimbulkan dampak terhadap lingkungan baik dampak positif maupun dampak negatif, yang perlu diperhatikan adalah bagaimana melaksanakan pembangunan untuk mendapatkan hasil dan manfaat yang maksimum dengan dampak negatif terhadap lingkungan yang minimum.

\section{Kinerja Mutu Pelaksanaan Proyek}

BS 5750 (1987) mendefinisikan kualitas sebagai totalitas fitur dan karakteristik dari suatu produk atau jasa yang memikul pada kemampuannya untuk memuaskan kebutuhan yang dinyatakan atau tersirat. Abdul Rahman (1994), menyatakan perusahaan konstruksi perlu mempertimbangkan kualitas dalam proses tender, tinjauan kontrak, perencanaan proyek, kontrol keuangan, seleksi subkontraktor dan pemasok, kepemimpinan dan pemanfaatan, alokasi sumber daya dan aspek manajemen lainnya.

Dalam industri konstruksi penekanannya adalah pada kemampuan memenuhi persyaratan yang telah ditetapkan. Persyaratan adalah karakteristik tetap pada sebuah produk, proses, atau jasa sebagaimana yang telah ditentukan dalam 
perjanjian kontrak, dan karakteristik adalah setiap spesifikasi atau property yang mendefinisikan sifat produk tersebut, proses atau jasa. Persyaratan awalnya ditentukan oleh klien dan kemudian diterjemahkan ke dalam desain konseptual oleh konsultan selanjutnya selama tahap perencanaan.

\section{METODE PENELITIAN}

Proses penelitian ini adalah menggunakan metode survey, dimana metode survey ini adalah penyelidikan yang diadakan untuk memperoleh fakta-fakta dari gejala-gejala yang ada dan mencari keteranganketerangan secara factual dan untuk mengidentifikasi pengelolaan faktor resiko yang mempengaruhi kinerja mutu pada pelaksanaan Proyek Jalan yang paling dominan berdasarkan kuesioner yang diisi oleh responden.

\section{Diagram Alir Penelitian}

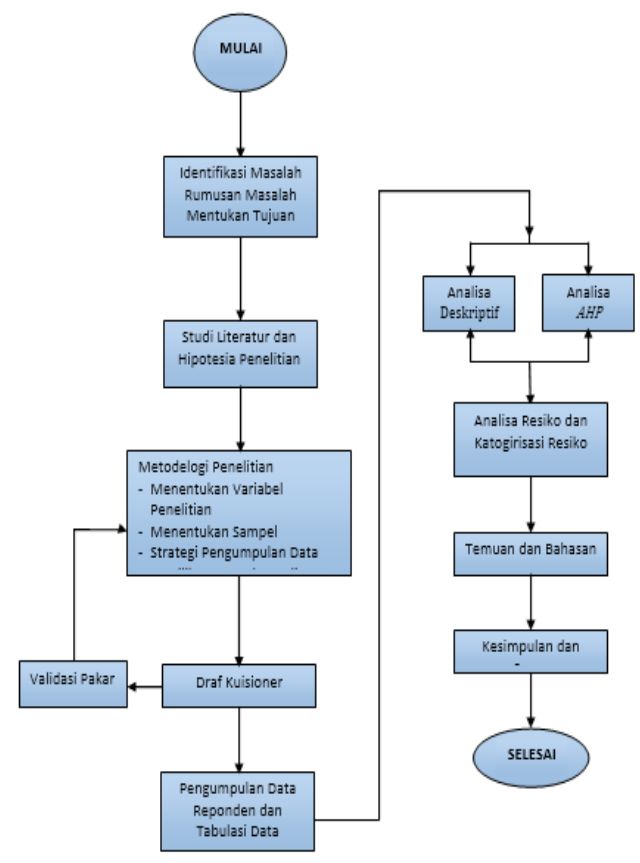

Gambar 1. Diagram Alir Penelitian

\section{Variabel Penelitian}

Pada kajian literature dan Identifikasi variabel-variabel didapat dari literatur yang juga tergambar pada kerangka berfikir dan data dari Penyedia Jasa Konstruksi (PJK), didapat variabelvariabel pemilihan sebagai berikut:

Tabel 1. Variabel Penelitian

\begin{tabular}{|c|c|c|c|c|c|}
\hline $\mathrm{X} 1$ & $\begin{array}{l}\text { Material yang } \\
\text { digunakan tidak sesuai } \\
\text { spesifikasi }\end{array}$ & $\mathrm{X} 21$ & Terlalu banyak lembur & X41 & $\begin{array}{l}\text { Penjadwalan proyek } \\
\text { tidak sempurna }\end{array}$ \\
\hline $\mathrm{X} 2$ & $\begin{array}{l}\text { Jumlah material yang } \\
\text { dibutuhkan tidak } \\
\text { cukup }\end{array}$ & $\mathrm{X} 22$ & $\begin{array}{l}\text { Metode pelaksanaan } \\
\text { tidak tepat }\end{array}$ & $\mathrm{X} 42$ & $\begin{array}{l}\text { Kurang komitmen } \\
\text { dalam hal Quality } \\
\text { Assurance dan } \\
\text { Quality Control }\end{array}$ \\
\hline $\mathrm{X} 3$ & $\begin{array}{l}\text { Kedatangan material } \\
\text { terlambat }\end{array}$ & $\mathrm{X} 23$ & $\begin{array}{l}\text { Jenis peralatan yang } \\
\text { digunakan tidak tepat }\end{array}$ & $\mathrm{X} 43$ & Keasalahan desain \\
\hline $\mathrm{X} 4$ & $\begin{array}{l}\text { Pengajuan contoh } \\
\text { bahan oleh kontraktor } \\
\text { yang tidak terjadwal }\end{array}$ & $\mathrm{X} 24$ & $\begin{array}{l}\text { Jumlah peralatan yang } \\
\text { digunakan kurang }\end{array}$ & X44 & $\begin{array}{l}\text { Penjadwalan proyek } \\
\text { yang ketat }\end{array}$ \\
\hline $\mathrm{X} 5$ & $\begin{array}{l}\text { Material Rusak dan } \\
\text { tidak sesuai }\end{array}$ & $\mathrm{X} 25$ & $\begin{array}{l}\text { Buruknya penataan site } \\
\text { lay out }\end{array}$ & $\mathrm{X} 45$ & $\begin{array}{l}\text { Spesifikasi sulit } \\
\text { dimengerti }\end{array}$ \\
\hline
\end{tabular}




\begin{tabular}{|c|c|c|c|c|c|}
\hline X6 & $\begin{array}{l}\text { Kemampuan tenaga } \\
\text { pelaksana proyek } \\
\text { kurang }\end{array}$ & $\mathrm{X} 26$ & $\begin{array}{l}\text { Perbedaan jadwal sub- } \\
\text { kontraktor dalam } \\
\text { penyelesaian proyek. }\end{array}$ & $\mathrm{X} 46$ & $\begin{array}{l}\text { Adanya perubahan } \\
\text { dasain dan lingkup } \\
\text { pekerjaan }\end{array}$ \\
\hline $\mathrm{X} 7$ & $\begin{array}{l}\text { Jumlah tenaga } \\
\text { pelaksana proyek } \\
\text { kurang }\end{array}$ & $\mathrm{X} 27$ & $\begin{array}{l}\text { Proses persetujuan } \\
\text { contoh bahan dengan } \\
\text { waktu yang lama oleh } \\
\text { pemilik. }\end{array}$ & $\mathrm{X} 47$ & $\begin{array}{l}\text { Gambar kerja tidak } \\
\text { jelas }\end{array}$ \\
\hline $\mathrm{X} 8$ & $\begin{array}{l}\text { Komunikasi antara } \\
\text { tenaga kerja dan } \\
\text { kepala tukang / } \\
\text { mandor. }\end{array}$ & $\mathrm{X} 28$ & $\begin{array}{l}\text { Keterlambatan proses } \\
\text { pemeriksaan dan uji } \\
\text { bahan. }\end{array}$ & $\mathrm{X} 48$ & $\begin{array}{l}\text { Lambat merevisi dan } \\
\text { mendistribusi } \\
\text { Gambar }\end{array}$ \\
\hline X9 & $\begin{array}{l}\text { Tingkat keahlian } \\
\text { tenaga kerja tidak } \\
\text { cukup }\end{array}$ & $\mathrm{X} 29$ & $\begin{array}{l}\text { Estimasi harga yang } \\
\text { kurang akurat }\end{array}$ & X49 & $\begin{array}{l}\text { Pengendalian } \\
\text { dokumen dilapangan } \\
\text { kurang baik }\end{array}$ \\
\hline $\mathrm{X} 10$ & $\begin{array}{l}\text { Jumlah tenaga kerja } \\
\text { kurang }\end{array}$ & X30 & $\begin{array}{l}\text { Kurangnya } \\
\text { kemampuan dalam } \\
\text { penanganan keuangan. }\end{array}$ & $\mathrm{X} 50$ & Cuaca kurang baik \\
\hline X11 & $\begin{array}{l}\text { Kualitas tim } \\
\text { engineering proyek } \\
\text { kurang baik }\end{array}$ & X31 & $\begin{array}{l}\text { Perubahan } \\
\text { desain/detail pekerjaan } \\
\text { pada waktu } \\
\text { pelaksanaan }\end{array}$ & $\mathrm{X} 51$ & $\begin{array}{l}\text { Kondisi lapangan } \\
\text { sulit }\end{array}$ \\
\hline X12 & $\begin{array}{l}\text { Jumlah personil tim } \\
\text { engineering proyek } \\
\text { kurang }\end{array}$ & X32 & $\begin{array}{l}\text { Rencana kerja pemilik } \\
\text { yang sering berubah- } \\
\text { ubah }\end{array}$ & $\mathrm{X} 52$ & $\begin{array}{l}\text { Adanya masalah } \\
\text { sosial }\end{array}$ \\
\hline X13 & $\begin{array}{l}\text { Kurangnya personil } \\
\text { pengalaman dan } \\
\text { keahlian dalam kontrak }\end{array}$ & X33 & $\begin{array}{l}\text { Banyak hasil pekerjaan } \\
\text { yang harus } \\
\text { diperbaiki/cacat atau } \\
\text { tidak benar. }\end{array}$ & $\mathrm{X} 53$ & $\begin{array}{l}\text { Adanya masalah } \\
\text { pembebasan lahan }\end{array}$ \\
\hline X14 & $\begin{array}{l}\text { Kopetensi personil } \\
\text { tidak sesuai dengan } \\
\text { tugas }\end{array}$ & X34 & $\begin{array}{l}\text { Buruknya komunikasi } \\
\text { dan koordinasi antar } \\
\text { organisasi kerja. }\end{array}$ & X54 & $\begin{array}{l}\text { Kerusakan oleh } \\
\text { pihak ke tiga }\end{array}$ \\
\hline $\mathrm{X} 15$ & $\begin{array}{l}\text { Tidak dilaksanakannya } \\
\text { review design sebelum } \\
\text { pelaksanaan } \\
\text { konstruksi. }\end{array}$ & X35 & $\begin{array}{l}\text { Tidak efektifnya atau } \\
\text { tidak adanya prosedur } \\
\text { manajemen kualitas }\end{array}$ & X55 & $\begin{array}{l}\text { Masalah peraturan } \\
\text { dan perijinan }\end{array}$ \\
\hline X16 & $\begin{array}{l}\text { Salah dalam } \\
\text { mengambil keputusan }\end{array}$ & X36 & $\begin{array}{l}\text { Tingginya frekwensi } \\
\text { perubahan pelaksanaan }\end{array}$ & - & - \\
\hline X17 & $\begin{array}{l}\text { Tidak memperhatikan } \\
\text { faktor resiko pada } \\
\text { lokasi dan konstruksi }\end{array}$ & X37 & $\begin{array}{l}\text { Distribusi data / } \\
\text { informasi kurang baik }\end{array}$ & - & - \\
\hline X18 & $\begin{array}{l}\text { Pembagian tugas dan } \\
\text { wewenang tidak jelas }\end{array}$ & X38 & $\begin{array}{l}\text { Komunikasi antar } \\
\text { pihak kurang baik }\end{array}$ & - & - \\
\hline X19 & $\begin{array}{l}\text { Kedisiplinan tenaga } \\
\text { kerja }\end{array}$ & X39 & $\begin{array}{l}\text { Alur koordinasi antar } \\
\text { pihak tidak jelas }\end{array}$ & - & - \\
\hline $\mathrm{X} 20$ & $\begin{array}{l}\text { Distribusi tenaga kerja } \\
\text { yang tidak merata }\end{array}$ & $\mathrm{X} 40$ & Kurangnya teamwork & - & - \\
\hline
\end{tabular}

\section{Pengumpulan Data}

Adapun teknik pengumpulan data dalam penelitian ini dilakukan dengan cara survei. Survei itu sendiri dilakukan dengan menggunakan cara kuesioner dan wawancara terhadap personil yang terlibat langsung dalam kegiatan pelaksanan proyek. Data yang akan diteliti dan 
dianalisa, data-data dalam penelitian ini terdiri dari data primer dan data sekunder.

Data primer didapat dengan melakukan studi lapangan. Studi lapangan merupakan cara pengumpulan data dengan melakukan wawancara dan hasil perolehan dari jawaban kuesioner para responden. Data sekunder merupakan data atau informasi yang diperoleh dari study literatur, seperti buku-buku, jurnal, makalah, penelitianpenelitian berkaitan sebelumnya, dan dapat juga disebut data yang sudah diolah.

\section{Analisis Data}

Analisa data secara statistic dengan menggunakan program Analytical Hierarchy Process (AHP). AHP merupakan metode untuk membuat urutan alternatif keputusan dan pemilihan alternatif terbaik pada saat pengambil keputusan dengan beberapa tujuan atau kriteria untuk mengambil keputusan.

Langkah pertama dalam melakukan analisis ini adalah membuat matriks berpasangan untuk frekuensi risiko dan dampak risiko yang diperoleh berdasarkan penilaian setiap kriterianya ditentukan sesuai dengan Tabel 2 yaitu tabel skala penilaian AHP. Untuk melakukan pembobotan dan penilaian risiko menggunakan metode Analisis Hirarki Proses (AHP), dimulai dengan membuat matriks berpasangan untuk dampak dan frekuensi risiko, menentukan pembobotan matriks, melakukan perhitungan konsistensi matriks, menentukan nilai faktor risiko, dan yang berikutnya adalah menentukan Level Risiko.

Tabel 2. Skala Penilaian Perbandingan Berpasangan

\section{Intensitas}

Kepentingan

\section{Keterangan}

Kedua elemen sama

1 pentingnya (Equal

Importance)

Elemen yang satu sedikit lebih penting daripada elemen yang lainnya (Slightly more Importance)

Elemen yang satu lebih penting daripada yang lainnya (Materially more Importance)

Satu elemen jelas lebih mutlak penting daripada

7 elemen lainnya

(Significantly more Importance)

Satu elemen mutlak penting 9 daripada elemen lainnya (Compromise values)

Nilai-nilai antara dua nilai pertimbangan pertimbangan yang berdekatan (Compromise values)

Sumber: Saaty, T.L. The Analytical Hierarchy Process: Planning, Priority Setting, Resource Allocation. Pittsburgh University Pers. 1990. P. 97 
Kategorisasi Resiko ini adalah cara untuk menentukan kategori resiko kedalam kelompok-kelompok berdasarkan tingkat resikonya. Untuk menentukan kategori variabel tersebut adalah dengan menggunakan tabel sebagai berikut:

Tabel 3. Kategorisasi Resiko

\begin{tabular}{|c|c|c|}
\hline $\begin{array}{l}\text { Nilai } \\
\text { FR }\end{array}$ & $\begin{array}{c}\text { Kategori } \\
\text { Resiko }\end{array}$ & $\begin{array}{c}\text { Langkah } \\
\text { Penanganan }\end{array}$ \\
\hline$>0.7$ & Tinggi & $\begin{array}{l}\text { Harus dilakukan } \\
\text { penurunan resiko ke } \\
\text { tingkat yang lebih } \\
\text { rendah }\end{array}$ \\
\hline $0.4-0.7$ & Sedang & $\begin{array}{lr}\text { Langkah } & \text { perbaikan } \\
\text { dibutuhkan } & \text { dalam } \\
\text { jangka } & \text { waktu } \\
\text { tertentu } & \end{array}$ \\
\hline$<0.4$ & Rendah & $\begin{array}{l}\text { Langkah perbaikan } \\
\text { bilamana } \\
\text { memungkinkan }\end{array}$ \\
\hline
\end{tabular}

\section{HASIL DAN PEMBAHASAN}

\section{Hasil Analisa Data Tahap Pertama}

Pada hasil pengumpulan data tahap pertama, yaitu dengan penyebaran kuisioner tahap pertama kepada pakar/ahli, Para pakar/ahli memberikan tanggapan, koreksi, masukkan, penambahan dan pengurangan pada setiap variable awal yang dimintakan pendapat kepada mereka. Dari hasil klarifikasi wawancara dengan para pakar/ahli terhadap variable penelitian didapat tanggapan, masukan, dan koreksi sehingga terjadi pengurangan jumlah variabe faktor-faktor resiko sebanyak 5 variabel, yang pada awalnya berjumlah 55 menjadi 50 variabel.

\section{Hasil Analisa Data Tahap Kedua}

Uji pilot survey adalah uji coba kuisioner kepada responden yang pada penelitian ini berjumlah 12 orang dengan tujuan untuk memberikan masukan mengenai kuisioner. Bisa meliputi apakah kata-katanya sudah mudah dimengerti, dan apakah petunjuk pengisian kuisioner mudah dipahami, agar pengisian bisa dilakukan dengan benar sehingga data yang didapatkan valid. Sebelum kuisioner tahap 2 disebar ke responden, kuisioner ini diuji coba kepada 12 orang. Dari 12 responden berpendapat bahwa kuesioner sudah cukup jelas.

\section{Hasil Analisa Data Tahap Ketiga}

Setelah kuisioner hasil dari masukan pilot survey, diperbaiki maka kuisioner dilanjutkan pada kuisioner tahap 3 dimana kuisioner di bagikan kepada para respnden yaitu para pelaku pelaksana proyek jalan jenis perkerasan lentur data hasil kuesioner tersebut kemudian melakukan pendalaman analisa. Diperoleh setelah pengujian validitas dan reliabilitas variabel resiko yang dihilangkan sebanyak 2 variabel yaitu variabel X7 dan X23.

\section{Hasil Analytical Hierarchy Process}

Analisa dengan metode AHP ini dimulai dengan perlakukan normalisasi matriks, perhitungan konsistensi matriks, konsistensi hirarki dan tingkat akurasi, 
kemudian dilakukan perhitungan untuk mencari nilai rata-rata dampak dan frekuensi.

\section{Perbandingan Berpasangan}

Matrik dibuat untuk perbandingan berpasangan, untuk masing-masing frekuensi dan dampak. Kemudian dilanjutkan dengan perbandingan berpasangan sehingga diperoleh sebanyak 5 buah elemen yang dibandingkan. Dibawah ini diberikan matriks berpasangan untuk dampak dan frekuensi

.Tabel 4. Matrik Berpasangan Untuk Dampak

\begin{tabular}{|c|c|c|c|c|c|}
\hline Kriteria & $\begin{array}{c}\text { Sangat } \\
\text { tinggi }\end{array}$ & Tinggi & Cukup & Rendah & $\begin{array}{c}\text { Sangat } \\
\text { Rendah }\end{array}$ \\
\hline Sangat Tinggi & 1.00 & 3.00 & 5.00 & 7.00 & 9.00 \\
\hline Tinggi & 0.33 & 1.00 & 3.00 & 5.00 & 7.00 \\
\hline Cukup & 0.20 & 0.33 & 1.00 & 3.00 & 5.00 \\
\hline Rendah & 0.14 & 0.20 & 0.33 & 1.00 & 3.00 \\
\hline Sangat Rendah & 0.11 & 0.14 & 0.20 & 0.33 & 1.00 \\
\hline Jumlah & $\mathbf{1 . 7 9}$ & $\mathbf{4 . 6 8}$ & $\mathbf{9 . 5 3}$ & $\mathbf{1 6 . 3 3}$ & $\mathbf{2 5 . 0 0}$ \\
\hline
\end{tabular}

Tabel 5. Matrik Berpasangan Untuk Frekuansi

\begin{tabular}{|c|c|c|c|c|c|}
\hline Kriteria & $\begin{array}{c}\text { Sangat } \\
\text { tinggi }\end{array}$ & Tinggi & Cukup & Rendah & $\begin{array}{c}\text { Sangat } \\
\text { Rendah }\end{array}$ \\
\hline Sangat Tinggi & 1.00 & 3.00 & 5.00 & 7.00 & 9.00 \\
\hline Tinggi & 0.33 & 1.00 & 3.00 & 5.00 & 7.00 \\
\hline Cukup & 0.20 & 0.33 & 1.00 & 3.00 & 5.00 \\
\hline Rendah & 0.14 & 0.20 & 0.33 & 1.00 & 3.00 \\
\hline Sangat Rendah & 0.11 & 0.14 & 0.20 & 0.33 & 1.00 \\
\hline Jumlah & $\mathbf{1 . 7 9}$ & $\mathbf{4 . 6 8}$ & $\mathbf{9 . 5 3}$ & $\mathbf{1 6 . 3 3}$ & $\mathbf{2 5 . 0 0}$ \\
\hline
\end{tabular}

\section{Bobot Elemen}

Perhitungan bobot elemen untuk masing- frekuensi maupun dampak dapat dilihat pada tabel dibawah ini.

masing unsur dalam matriks baik untuk

Tabel 6. Perhitungan Bobot Elemen Untuk Dampak

\begin{tabular}{|c|c|c|c|c|c|c|c|}
\hline Kriteria & $\begin{array}{c}\text { Sangat } \\
\text { tinggi }\end{array}$ & Tinggi & Cukup & Rendah & $\begin{array}{c}\text { Sangat } \\
\text { Rendah }\end{array}$ & Jumlah & Prioritas \\
\hline Sangat Tinggi & 0.560 & 0.642 & 0.524 & 0.429 & 0.360 & $\mathbf{2 . 5 1 4}$ & $\mathbf{0 . 5 0 3}$ \\
\hline Tinggi & 0.187 & 0.214 & 0.315 & 0.306 & 0.280 & $\mathbf{1 . 3 0 1}$ & $\mathbf{0 . 2 6 0}$ \\
\hline Cukup & 0.112 & 0.071 & 0.105 & 0.184 & 0.200 & $\mathbf{0 . 6 7 2}$ & $\mathbf{0 . 1 3 4}$ \\
\hline
\end{tabular}


ISSN 1979-4835

\begin{tabular}{|c|c|c|c|c|c|c|c|}
\hline Rendah & 0.080 & 0.043 & 0.035 & 0.061 & 0.120 & $\mathbf{0 . 3 3 9}$ & $\mathbf{0 . 0 6 8}$ \\
\hline Sangat Rendah & 0.062 & 0.031 & 0.021 & 0.020 & 0.040 & $\mathbf{0 . 1 7 4}$ & $\mathbf{0 . 0 3 5}$ \\
\hline Jumlah & $\mathbf{1 . 0 0 0}$ & $\mathbf{1 . 0 0 0}$ & $\mathbf{1 . 0 0 0}$ & $\mathbf{1 . 0 0 0}$ & $\mathbf{1 . 0 0 0}$ & $\mathbf{5 . 0 0 0}$ & \\
\hline
\end{tabular}

Tabel 7. Bobot Eleman Dampak

\begin{tabular}{|c|c|c|c|c|c|}
\hline & $\begin{array}{c}\text { Sangat } \\
\text { Rendah }\end{array}$ & Rendah & Cukup & Tinggi & $\begin{array}{c}\text { Sangat } \\
\text { Tinggi }\end{array}$ \\
\hline Bobot & 0.069 & 0.134 & 0.267 & 0.517 & 1 \\
\hline
\end{tabular}

Sumber: Hasil Olahan Peneliti, 2018

Perhitungan bobot elemen untuk unsur frekuensi, dilakukan dengan cara yang sama dengan perhitungan bobot elemen dampak, yang diperlihatkan pada tabel dibawah ini.

Tabel 8. Perhitungan Bobot Elemen Untuk Frekuensi

\begin{tabular}{|c|c|c|c|c|c|c|c|}
\hline Kriteria & $\begin{array}{c}\text { Sangat } \\
\text { tinggi }\end{array}$ & Tinggi & Cukup & Rendah & $\begin{array}{c}\text { Sangat } \\
\text { Rendah }\end{array}$ & Jumlah & Prioritas \\
\hline Sangat Tinggi & 0.560 & 0.642 & 0.524 & 0.429 & 0.360 & $\mathbf{2 . 5 1 4}$ & $\mathbf{0 . 5 0 3}$ \\
\hline Tinggi & 0.187 & 0.214 & 0.315 & 0.306 & 0.280 & $\mathbf{1 . 3 0 1}$ & $\mathbf{0 . 2 6 0}$ \\
\hline Cukup & 0.112 & 0.071 & 0.105 & 0.184 & 0.200 & $\mathbf{0 . 6 7 2}$ & $\mathbf{0 . 1 3 4}$ \\
\hline Rendah & 0.080 & 0.043 & 0.035 & 0.061 & 0.120 & $\mathbf{0 . 3 3 9}$ & $\mathbf{0 . 0 6 8}$ \\
\hline Sangat Rendah & 0.062 & 0.031 & 0.021 & 0.020 & 0.040 & $\mathbf{0 . 1 7 4}$ & $\mathbf{0 . 0 3 5}$ \\
\hline Jumlah & $\mathbf{1 . 0 0 0}$ & $\mathbf{1 . 0 0 0}$ & $\mathbf{1 . 0 0 0}$ & $\mathbf{1 . 0 0 0}$ & $\mathbf{1 . 0 0 0}$ & $\mathbf{5 . 0 0 0}$ & \\
\hline
\end{tabular}

Tabel 9. Bobot Eleman Untuk Frekuensi

\begin{tabular}{|c|c|c|c|c|c|}
\hline & $\begin{array}{c}\text { Sangat } \\
\text { Rendah }\end{array}$ & Rendah & Cukup & Tinggi & $\begin{array}{c}\text { Sangat } \\
\text { Tinggi }\end{array}$ \\
\hline Bobot & 0.069 & 0.134 & 0.267 & 0.517 & 1 \\
\hline
\end{tabular}

\section{Uji Konsistensi Matriks dan Hirarki}

Matriks bobot dari hasil perbandingan berpasangan harus mempunyai diagonal bernilai satu dan konsisten. Untuk menguji konsistensi, maka nilai eigen value maksimum ( $\lambda$ maks) harus mendekati banyaknya elemen (n) dan rasio konsistensi kurang dari 0.1. Pembuktian konsistensi matriks berpasangan dilakukan dengan unsur- unsur pada tiap kolom 
dibagi dengan jumlah kolom yang berikut:

bersangkutan diperoleh matriks sebagai

\begin{tabular}{|c|c|c|c|c|c|}
\hline & Sangat tinggi & Tinggi & Cukup & Rendah & Sangat Rendah \\
\hline Sangat Tinggi & 0.560 & 0.642 & 0.524 & 0.429 & 0.360 \\
\hline Tinggi & 0.187 & 0.214 & 0.315 & 0.306 & 0.280 \\
\hline Cukup & 0.112 & 0.071 & 0.105 & 0.184 & 0.200 \\
\hline Rendah & 0.080 & 0.043 & 0.035 & 0.061 & 0.120 \\
\hline Sangat Rendah & 0.062 & 0.031 & 0.021 & 0.020 & 0.040 \\
\hline
\end{tabular}

Vektor kolom (rata-rata) dikalikan dengan matriks semula menghasilkan nilai untuk tiap baris, yang selanjutnya setiap nilai dibagi kembali dengan nilai vektor yang bersangkutan:

$$
\begin{gathered}
\lambda_{\text {maks }}=((1.78 \times 0.503)+(4.67 \times 0.260) \\
\quad+(9.53 \times 0.134) \\
+(16.33 \times 0.067) \\
\quad+(25 \times 0.034)=5.35 \\
C C I=\frac{\lambda_{\text {maks }}-n}{n-1}=\frac{5.35-5}{5-1}=0.089 \\
C R I=\frac{(1.98(n-2))}{n}=1.188 \\
C R=\frac{C C I}{C R I}=\frac{0.089}{1.188}=0.075
\end{gathered}
$$

Banyaknya elemen dalam matriks (n) adalah 5, maka $\lambda$ maks $=5.35$, dengan demikian karena nilai $\lambda$ maks mendekati banyaknya elemen (n) dalam matriks yaitu 5 dan diperoleh nilai ratio konsistensi sebesar 0.075 maka nilai tersebut kurang 0.1, maka matriks adalah konsisten. Matriks berpasangan untuk dampak dan frekuensi adalah sama sesuai dengan tabel 4 dan 5 maka hasil ini sama untuk dampak dan frekuensi, yaitu masing-masing matriks konsisten.

\section{Analisa Nilai Faktor Resiko}

Setelah didapatkan nilai rata-rata dampak dan frekuensi resiko, analisa dilanjutkan dengan mencari nilai Faktor Resiko. Persamaan faktor reisiko didefinisikan sebagai perkalian antara besaran dampak dan probabilitas kejadian resiko, yang dihitung dari persamaan berikut ini, yaitu:

$$
\mathbf{F R}=\mathbf{L}+\mathbf{I}-(\mathbf{L} \times \mathbf{I}),
$$

Sumber: RSNI (2006)

Dengan pengertian:

$\mathrm{FR}=$ Faktor resiko, dengan skala $0-1$

$\mathrm{L}=$ Probabilitas kejadian resiko,

$\mathrm{I}=$ Besaran dampak (impact) resiko

Sebagai contoh untuk variabel $\mathrm{X} 1$, nilai rata-rata Probabilitas Kejadian Resiko adalah sebesar: 0.285, untuk nilai Dampak Kejadian Resiko adahlah sebesar 0.559, maka besaran Faktor Resikonya adalah:

FR X1 $=0.285+0.559-(0.285 \times 0.559)$ 
FR X1 $=0.713$

Adapun tabel rekapitulasi nulai dari hasil keseluruhan variable / peristiwa resiko adalah sebagai berikut:

perhitungan Faktor Resiko untuk

Tabel 10. Kategori Risiko Aspek Material

\begin{tabular}{|c|l|c|c|}
\hline Variabel & \multicolumn{1}{|c|}{ Peristiwa Resiko } & Faktor Resiko & Kategori \\
\hline X1 & $\begin{array}{l}\text { Material yang digunakan tidak sesuai } \\
\text { spesifikasi }\end{array}$ & 0.713 & Tinggi \\
\hline X2 & $\begin{array}{l}\text { Jumlah material yang dibutuhkan tidak } \\
\text { cukup }\end{array}$ & 0.598 & Sedang \\
\hline X3 & Kedatangan material terlambat & 0.579 & Sedang \\
\hline X4 & $\begin{array}{l}\text { Pengajuan contoh bahan oleh } \\
\text { kontraktor yang tidak terjadwal }\end{array}$ & 0.479 & Sedang \\
\hline X5 & Material Rusak dan tidak sesuai & 0.618 & Sedang \\
\hline
\end{tabular}

Hasil dari kategorisasi resiko pada aspek material menunjukkan bahwa peristiwa resiko yang dikategorikan tinggi adalah variabel X1, dan yang dikategorikan sedang adalah variabel X2, X3, X4, X5 .

Tabel 11. Kategori Risiko Aspek Sumber Daya Manusia

\begin{tabular}{|c|l|c|c|}
\hline Variabel & \multicolumn{1}{|c|}{ Peristiwa Resiko } & Faktor Resiko & Kategori \\
\hline X6 & $\begin{array}{l}\text { Kemampuan tenaga pengawas proyek } \\
\text { kurang }\end{array}$ & 0.624 & Sedang \\
\hline X8 & $\begin{array}{l}\text { Komunikasi antara tenaga kasar dan } \\
\text { kepala tukang / mandor. }\end{array}$ & 0.564 & Sedang \\
\hline X9 & $\begin{array}{l}\text { Tingkat keahlian tenaga kasar tidak } \\
\text { cukup }\end{array}$ & 0.573 & Sedang \\
\hline X10 & Jumlah tenaga kerja kurang & 0.674 & Sedang \\
\hline X11 & $\begin{array}{l}\text { Kualitas tim engineering proyek kurang } \\
\text { baik }\end{array}$ & 0.760 & Tinggi \\
\hline X12 & $\begin{array}{l}\text { Jumlah personil tim engineering proyek } \\
\text { kurang }\end{array}$ & 0.637 & Sedang \\
\hline X13 & $\begin{array}{l}\text { Kurangnya personil pengalaman dan } \\
\text { keahlian dalam kontrak }\end{array}$ & 0.532 & Sedang \\
\hline X14 & $\begin{array}{l}\text { Kompetensi personil tidak sesuai dengan } \\
\text { tugas }\end{array}$ & 0.777 & Tinggi \\
\hline X15 & $\begin{array}{l}\text { Tidak dilaksanakannya review design } \\
\text { sebelum pelaksanaan konstruksi. }\end{array}$ & 0.525 & Sedang \\
\hline X16 & Salah dalam mengambil keputusan & 0.588 & Sedang \\
\hline X17 & $\begin{array}{l}\text { Tidak memperhatikan faktor resiko pada } \\
\text { lokasi dan konstruksi }\end{array}$ & 0.740 & Tinggi \\
\hline X18 & $\begin{array}{l}\text { Pembagian tugas dan wewenang tidak } \\
\text { jelas }\end{array}$ & 0.676 & Sedang \\
\hline
\end{tabular}




\begin{tabular}{|c|l|c|c|}
\hline Variabel & \multicolumn{1}{|c|}{ Peristiwa Resiko } & Faktor Resiko & Kategori \\
\hline X19 & Kedisiplinan tenaga kerja & 0.746 & Tinggi \\
\hline X20 & Distribusi tenaga kerja yang tidak merata & 0.493 & Sedang \\
\hline X21 & Terlalu banyak lembur & 0.442 & Sedang \\
\hline
\end{tabular}

Hasil dari kategorisasi resiko pada aspek material menunjukan bahwa peristiwa resiko yang dikategorikan sedang adalah variabel X11, X17, dan X19. Untuk variabel dengan kategori resiko tinggi adalah variabel X6, X8, X9, X10, X12, X13, X14, X15, X16, X18, X20 dan X21.

Tabel 12. Kategori Risiko Aspek Metode dan Peralatan

\begin{tabular}{|c|l|c|c|}
\hline Variabel & Peristiwa Resiko & Faktor Resiko & Kategori \\
\hline X22 & Metode pelaksanaan tidak tepat & 0.709 & Tinggi \\
\hline X24 & Jumlah peralatan yang digunakan kurang & 0.630 & Sedang \\
\hline X25 & Buruknya penataan site lay out & 0.573 & Sedang \\
\hline
\end{tabular}

Sumber: Hasil Olahan Peneliti, 2018

Hasil dari kategorisasi resiko pada aspek material menunjukkan bahwa peristiwa resiko yang dikategorikan tinggi adalah variabel X22. Untuk variabel dengan kategori resiko sedang terdapat pada variabel X24 dan X25

Tabel 13. Kategori Resiko Aspek Manajerial

\begin{tabular}{|c|l|c|c|}
\hline Variabel & \multicolumn{1}{|c|}{ Peristiwa Resiko } & Faktor Resiko & Kategori \\
\hline X26 & $\begin{array}{l}\text { Perbedaan jadwal sub-kontraktor dalam } \\
\text { penyelesaian proyek }\end{array}$ & 0.553 & Sedang \\
\hline X28 & $\begin{array}{l}\text { Keterlambatan proses pemeriksaan dan } \\
\text { uji bahan. }\end{array}$ & 0.460 & Sedang \\
\hline X29 & Estimasi harga yang kurang akurat & 0.487 & Sedang \\
\hline X30 & $\begin{array}{l}\text { Kurangnya kemampuan dalam } \\
\text { penanganan keuangan. }\end{array}$ & 0.506 & Sedang \\
\hline X31 & $\begin{array}{l}\text { Perubahan desain/detail pekerjaan pada } \\
\text { waktu pelaksanaan }\end{array}$ & 0.451 & Sedang \\
\hline X32 & $\begin{array}{l}\text { Rencana kerja pemilik yang sering } \\
\text { berubah-ubah }\end{array}$ & 0.675 & Sedang \\
\hline X33 & $\begin{array}{l}\text { Banyak hasil pekerjaan yang harus } \\
\text { diperbaiki/cacat atau tidak benar. }\end{array}$ & 0.502 & Sedang \\
\hline
\end{tabular}


ISSN 1979-4835

\begin{tabular}{|c|l|c|c|}
\hline Variabel & \multicolumn{1}{|c|}{ Peristiwa Resiko } & Faktor Resiko & Kategori \\
\hline X34 & $\begin{array}{l}\text { Buruknya komunikasi dan koordinasi } \\
\text { antar organisasi kerja }\end{array}$ & 0.741 & Tinggi \\
\hline X35 & $\begin{array}{l}\text { Tidak efektifnya atau tidak adanya } \\
\text { prosedur manajemen kualitas }\end{array}$ & 0.575 & Sedang \\
\hline X36 & $\begin{array}{l}\text { Tingginya frekwensi perubahan } \\
\text { pelaksanaan }\end{array}$ & 0.630 & Sedang \\
\hline X37 & Distribusi data / informasi kurang baik & 0.477 & Sedang \\
\hline X38 & Komunikasi antar pihak kurang baik & 0.700 & Tinggi \\
\hline X39 & Alur koordinasi antar pihak tidak jelas & 0.698 & Sedang \\
\hline X40 & Kurangnya teamwork & 0.655 & Sedang \\
\hline X41 & Penjadwalan proyek tidak sempurna & 0.521 & Sedang \\
\hline X42 & $\begin{array}{l}\text { Kurang komitmen dalam hal Quality } \\
\text { Assurance dan Quality Control }\end{array}$ & 0.714 & Tinggi \\
\hline
\end{tabular}

Hasil dari kategorisasi resiko pada aspek adalah variabel X26, X28, X29, X30, X31, manajerial menunjukan bahwa peristiwa X32, X33, 35, X36, X37, X39, X40, X41 resiko yang dikategorikan tinggi adalah dan X42 pada aspek Manajerial. variable X34 dan X38. Kategori sedang

Tabel 14. Kategori Resiko Aspek Desain dan Dokumentasi

\begin{tabular}{|c|c|c|c|}
\hline Variabel & Peristiwa Resiko & Faktor Resiko & Kategori \\
\hline X43 & Kesalahan desain & 0.713 & Tinggi \\
\hline $\mathrm{X} 44$ & Penjadwalan proyek yang ketat & 0.720 & Tinggi \\
\hline X45 & Spesifikasi sulit dimengerti & 0.651 & Sedang \\
\hline $\mathrm{X} 46$ & $\begin{array}{c}\text { Adanya perubahan dasain dan lingkup } \\
\text { pekerjaan }\end{array}$ & 0.553 & Sedang \\
\hline X47 & Gambar kerja tidak jelas & 0.617 & Sedang \\
\hline $\mathrm{X} 48$ & $\begin{array}{l}\text { Lambat merevisi dan mendistribusi } \\
\text { Gambar }\end{array}$ & 0.431 & Sedang \\
\hline X49 & $\begin{array}{c}\text { Pengendalian dokumen dilapangan } \\
\text { kurang baik }\end{array}$ & 0.422 & Sedang \\
\hline $\mathrm{X} 50$ & Cuaca kurang baik (Hujan dan Banjir) & 0.464 & Sedang \\
\hline
\end{tabular}




\begin{tabular}{|c|c|c|c|}
\hline X54 & Kerusakan oleh pihak ke tiga & 0.469 & Sedang \\
\hline
\end{tabular}

Hasil dari kategorisasi resiko pada aspek

Desain dan Dokumentasi menunjukkan bahwa peristiwa resiko yang dikategorikan sedang adalah variabel X37, X45, X46, X47. Untuk variabel dengan kategori resiko tinggi tidak terdapat pada aspek Desain dan Dokumentasi.

Pada tabel kategori resiko tersebut diatas, didapat bahwa resiko dengan kategori tinggi adalah $m$ aterial yang digunakan tidak sesuai spesifikasi, kualitas tim engineering proyek kurang baik, Kompetensi personil tidak sesuai dengan tugas, Tidak memperhatikan faktor resiko pada lokasi dan konstruksi, Kedisiplinan tenaga kerja, Metode pelaksanaan tidak tepat, Buruknya komunikasi dan koordinasi antar organisasi kerja, Komunikasi antar pihak kurang baik, Kurang komitmen dalam hal Quality Assurance dan Quality Control, Kesalahan desain dan Penjadwalan proyek.

Hasil perhitungan diatas menunjukkan bahwa nilai faktor resiko tinggi didapat jika salah satu besaran dari probabilitas atau dampak sangat tinggi, atau besaran nilai keduanya tinggi. Faktor-faktor resiko tinggi memper adalah tinggi. Dari hal tersebut jelas bahwa untuk mengurangi level resiko, maka perusahaan haruslah memperhatikan material yang digunakan, kualitas tim engineering, Kompetensi personil, lokasi dan konstruksi, Kedisiplinan tenaga kerja, Metode pelaksanaan, komunikasi dan koordinasi antar organisasi kerja, komitmen dalam Quality Assurance dan Quality Control, Desain dan Penjadwalan proyek.

\section{PEMBAHASAN}

Hasil dari pengumpulan data yang disebar, setelah diuji dengan dianalisa dengan menggunakan analisa Deskriptif dan AHP, maka didapatkan bahwa data X7 dan X23 tidak valid. Instrumen yang digunakan reliabel. Dari 48 resiko diantaranya 11 peristiwa resiko dalam kategori tinggi dan 37 peristiwa resiko dengan kategori sedang.

Material merupakan komponen terbesar didalam pelaksanaan proyek dapat diintegrasikan dengan teknik untuk menyediakan produk akhir yang memenuhi kebutuhan klien dan biaya yang efektif. Manajemen material adalah pengelolaan; proses perencanaan, pengorganisasian, pelaksanaan, dan pengendalian. Manajemen Material merupakan semua aktifitas yang dibutuhkan untuk mengatur aliran bahan baku (material) dari suplier melalui aktifitas sebuah sistem manajemen yang mengintegrasikan wilayah pembelian, 
memperlancar dan mengendalikan kemajuan dari vendor. Ini adalah bagian penting dari manajemen proyek dan biaya yang efektif. Hinzen \& Kuchenmeister (1981), menyatakan bahwa faktor yang memperendah kinerja proyek salah satunya adalah material yang tidak sesuai spesifikasi. Dari hasil analisa ditemukan bahwa pengaruh peristiwa resiko material yang digunakan tidak sesuai spesifikasi (X1) terhadap kinerja mutu adalah dikategorikan tinggi terhadap kinerja mutu proyek jalan. Persyaratan atas spesifikasi material yang digunakan dalam pelaksaan adalah syarat mutlak yang harus dipenuhi. Kesalahan didalam mengidentifikasi jenis dan spesifikasi material didalam proses perencanaan akan berakibat material yang didatangkan tidak sesuai spesifikasi. Bahan konstruksi yang dibutuhkan untuk pekerjaan proyek bervariasi dengan proyek. Selain disebabkan oleh tidak baiknya proses perencanaan pengadan material, tidak terpenuhinya persyaratan spesifikasi material ini juga bisa disebabkan oleh buruknya proses pengendalian material tersebut, termasuk pada proses pengiriman, penerimaan material, dan proses pengiriman material. Pada proses pengiriman/distribusi, penyimpanan, dan handling material yang tidak baik bisa menyebabkan kerusakan material sehingga tidak memenuhi persyaratan konstruksi, untuk itu pengendalian pada proses-proses tersebut harus dilakukan dengan baik. Oleh sebab itu material harus dikelola dengan baik.

Sumber Daya Manusia adalah seorang yang siap, mau dan mampu memberi sumbangan usaha pencapaian tujuan organisasi. Selain itu SDM merupakan salah satu unsur masukan (input) yang bersama unsur lainnya seperti modal, bahan, mesin, dan metode/teknologi diubah menjadi proses manajemen menjadi keluaran (output) berupa barang atau jasa dalam usaha mencapa tujuan kontraktor. Manajemen Sumber Daya Manusia (MSDM) merupakan bagian dari manajemen keorganisasian yang memfokuskan diri pada unsure sumber daya manusia. Adalah tugas manajemen sumber daya manusia untuk mengelola unsur manusia secara baik agar diperoleh tenaga kerja yang puas akan pekerjaannya. Hasil temuan menunjukan bahwa ada 4 peristiwa penting dari aspek SDM ini masuk kedalam kategori tinggi yaitu Kualitas tim engineering proyek kurang baik (X11), Kompetensi personil tidak sesuai dengan tugas (X14), Tidak memperhatikan faktor resiko pada lokasi dan konstruksi (X17), dan Kedisiplinan tenaga kerja (X19). Pengelolaan sumber daya manusia pada sebuah proyek memiliki dampak besar pada keberhasilan atau kegagalan proyek itu sendiri. Perencanaan tenaga kerja proyek 
diutamakan dengan perkiraan produktifitas tenaga kerja, penjadwalan tenaga kerja, menstrukturkan kedalam tim dan grup tenaga kerja, dengan melihat dari segi ekonomois dan persyaratan tenaga kerja (Hendra, 2007).

Setiap proyek memiliki tujuan khusus, dimana masing-masing tujuan tersebut didalamnya terdapat batasan yang mendasar yaitu besarnya biaya yang dianggarkan, waktu yang dijadwalkan dan mutu yang harus dipenuhi. Aspek teknologi sangat berperan dalam suatu proyek konstruksi. Umumnya, aplikasi teknologi ini banyak diterapkan dalam metode - metode pelaksanaan pekerjaan Proyek Jalan. Hasil temuan menunjukan bahwa satu peristiwa penting dari aspek metode dan peralatan yang dikategorikan tinggi yaitu Metode pelaksanaan tidak tepat (X22). Dalam pelaksanaan pekerjaan konstruksi, adakalanya juga diperlukan suatu metode terobosan untuk menyelesaikan pekerjaan lapangan. Khususnya pada saat menghadapi kendala-kendala yang diakibatkan oleh kondisi lapangan yang tidak sesuai dengan dugaan sebelumnya. Untuk itu, penerapan metode pelaksanaan konstruksi yang sesuai kondisi lapangan, akan sangat membantu dalam penyelesaian proyek konstruksi bersangkutan. Metode pelaksanaan yang digunakan jika tidak tepat akan berpengaruh langsung terhadap mutu pekerjaan.

Manajemen proyek dapat didefinisikan sebagai suatu proses dari perencanaan, pengaturan, kepemimpinan, dan pengendalian dari suatu proyek oleh para anggotanya dengan memanfaatkan sumber daya seoptimal mungkin untuk mencapai sasaran yang telah ditentukan. Dengan adanya manajemen proyek maka akan terlihat batasan mengenai tugas, wewenang, dan tanggung jawab dari pihak-pihak yang terlibat dalam proyek baik langsung maupun tidak langsung, sehingga tidak akan terjadi adanya tugas dan tangung jawab yang dilakukan secara bersamaan (overlapping). Hasil temuan menunjukan bahwa tiga peristiwa resiko penting dari aspek manajerial yang dikategorikan tinggi yaitu buruknya komunikasi dan koordinasi antar organisasi kerja (X34), Komunikasi antar pihak kurang baik (X38) dan Kurang komitmen dalam hal Quality Assurance dan Quality Control (X42).

Peristiwa resiko pada aspek desian dan dokumentasi terdapat dua peristiwa resiko yaitu Kesalahan desain (X34) dan Penjadwalan proyek yang ketat (X44). Menurut Al-Hazmi (1987), dokumendokumen yang dibutuhkan untuk konstruksi penting untuk mencapai ketepatan waktu dan keberhasilan proyek. Dengan adanya jadwal proyek yang ketat akan terjadi banyak permasalahan didalam 
proses pelaksanaan. Pada proses perencanaan juga tentunya akan ditarget dengan waktu yang ketat, dengan waktu yang ketat akan menghasilkan perencanaan yang tidak sempurna.

\section{KESIMPULAN DAN SARAN}

\section{Kesimpulan}

Berdasarkan hasil peneltian mengenai Analisa Pengelolaan Fakor Resiko Yang Mempengaruhi Kinerja Mutu Pada Pelaksanaan Proyek Jalan maka penulis dapat memberikan kesimpulan sebagai berikut:

1. Peristiwa resiko yang masuk dalam kategori tinggi pada pelaksanaan proyek jalan di Jalan Ciamis - Banjar - Pengandaran - Batas Jateng antara lain, sebagai berikut:

- Material yang digunakan tidak sesuai spesifikasi

- Kualitas tim engineering proyek kurang baik

- Kompetensi personil tidak sesuai dengan tugas

- Tidak memperhatikan faktor resiko pada lokasi dan konstruksi

- Kedisiplinan tenaga kerja

- Buruknya komunikasi dan koordinasi antar organisasi kerja

- Komunikasi antar pihak kurang baik

- Kurang komitmen dalam hal
Quality Assurance dan Quality Control

- Kesalahan desain

- Penjadwalan proyek yang ketat

2. Dampak dari peristiwa resiko pada aspek material adalah berakibat langsung dengan mutu hasil pekerjaan. Dampak dari peristiwa resiko pada aspek sumber daya manusia adalah pengawasan, instruksi kerja, dan pelaksanaan pekerjaan menjadi kurang baik. Dampak dari peristiwa resiko pada aspek metode dan peralatan adalah mutu hasil proyek tidak sesuai dengan spesifikasi, pelaksanaan proyek dilapangan tidak teratur. Dampak dari peristiwa resiko pada aspek manajerial adalah pada saat pelaksanaan pekerjaan terjadi miss komunikasi dan kendala lainnya, serta akan terjadi pelaksanaan pekerjaan yang terburu-buru akibat penjadwalan yang tidak sempurna. Sedangkan dampak dari peristiwa resiko pada aspek desian dan dokumentasi adalah pelaksanaan akan dilakukan secara terburu-buru, salah dalam membaca dan acuan.

3. Adapun tindakan yang harus diambil untuk mengatasi risiko-risiko pada semua aspek pelaksanaan tersebut, yaitu dimulai ketika proses perencanaan, dimana semua aspek 
harus direncanakan dengan sebaikbaiknya agar tidak terjadi kesalahan yang berimbas pada saat pelaksanaan yang tidak berjalan sesuai dengan harapan. Pada proses pelaksanaan agar semua yang telah direncanakan akan menjadi acuan pelaksanaan, sehingga perlu dilakukan proses pengawasan untuk memastikan bahwa apa yang direncanakan sesuai dengan yang dilaksanakan. Monitoring dan evaluasi akan menjadi tools dan pertimbangan untuk melakukan tindakan yang diperlukan dalam pelaksanaan pekerjaan. Perlu dibuat prosedur dan instruksi kerja pada setiap aktifitas, baik pada proses perencanaan, pelaksanaan, maupun proses pengendalian. Prosedur dan instruksi kerja tersebut dipastikan dipahami dan dijalankan oleh semua pihak yang terlibat dengan cara sosialisasi dan audit dari implementasinya.

\section{Saran}

Berdasarkan hasil penelitian dan kesimpulan yang telah dipaparkan, peneliti akan mengajukan saran-saran dengan harapan dapat bermanfaat bagi semua pihak yang berkepentingan. Ada pun saran-saran yang akan peneliti kemukakan adalah sebagi berikut:

1. Untuk penelitian selanjutnya diharapkan melakukan penelitian lebih mendetail untuk menganalisa lebih mendalam mengenai pengaruh dari salah satu aspek persistiwa resiko yaitu: aspek material, aspek sumber daya manusia, aspek metode dan peralatan, aspek manajerial, dan aspek desain dan dokumentasi

2. Untuk penelitian selanjutnya dapat mengembangkan penelitian ini dengan menggunakan metode lain dalam meneliti pengelolaan fakor resiko yang mempengaruhi kinerja mutu sehingga informasi yang diperoleh dapat lebih bervariasi mengenai peningkatan kinerja mutu dalam proyek.

\section{DAFTAR PUSTAKA}

Ahadzie, D. K. et al. (2006). Critical success criteria for mass house building projects in developing countries. International Journal of Project Management, Vol. 26, pp. 675-687.

Cleland, D. I., \& King, W. R. (1987). Systems Analysis and Project Management. New York: Mc GrawHill.

Crosby, P. B. (1979). Quality is Free: The Art of Making Quality Certain. New York: McGraw-Hill.

Fandofa, Riza. (2012). Pengelolaan Resiko Pada Pelaksanaan Proyek Jalan Perkerasan Lentur PT X Dalam Rangka Meningkatkan Kinerja Mutu Proyek. Tesis. Fakultas Teknik Program Studi Teknik Sipil Kekhususan Manajemen Proyek. Jakarta. 
Lim C.S. dan Mohamed, M. Z. (1999). Criteria of project success. International Journal of Project Management, Vol 17, No.4, pp 243248.

Nurdiana, Asri. (2011). Aplikasi Manajemen Resiko Dari Persepsi Para Stakeholders (Studi Kasus Proyek Pembangunan Jalan Tol Semarang-Solo Seksi I Ruas Tembalang-Gedawang). Tesis. Universitas Diponegoro. Semarang.

Peraturan Presiden Nomor 54 tahun 2010 tentang Pedoman Pengadaan Barang dan Jasa.

Peraturan Presiden Nomor 70 Tahun 2012 Tentang Perubahan Kedua Atas Peraturan Presiden Nomor 54 Tahun 2010 Tentang Pengadaan Barang/Jasa Pemerintah.

Peraturan Presiden Republik Indonesia Nomor 4 Tahun 2015 tentang Perubahan Keempat atas Peraturan Peraturan Presiden Nomor 54 Tahun 2010 tentang Pengadaan Barang/Jasa Pemerintah.

Perry and Hayes. (1985). Risk and its Management in Contruction Period. Institution of Civil Engineers. Proceedings. (Engineering and Management Group) 78. June, pp 499-521.

Soeharto, I. (2001). Manajemen proyek dari konseptual sampai operasional. Penerbit Erlangga, Jakarta.

Soemarno. (2008). Manajemen Resiko Proyek Kontruksi, Resiko dan Analisisnya.

Thompson, P., \& Perry, J. (1992). Engineering Construction Risk. London Thomas Telford Ltd.

Uher, Thomas. E. (1996). Programming and Scheduling Techniques. Australia, School of Building the University of New South Wales.
Umar, Husein. (2004). Sumber Daya Manusia Dalam Organisasi. Jakarta: PT.SUN.

Undang-Undang Republik Indonesia Nomor 18 Tahun 1999 Tentang Jasa Konstruksi.

Whitten L, Jeffery., Bentley D, Lonnie., and Dittman C, Kevin. (2004). Metode Desain dan Analisis Sistem. Terjemahan oleh Tim Penerjemah ANDI. ANDI: Yogyakarta.

Winata, Andi dan Samuel, Y. (2005). Faktor-Faktor penyeba Rework pada Pekerjaan Konstruksi. Universitas Kristen Petra. Dimensi Teknik Sipil.

Wysocki, R.K., Beck, Jr., R., Crane, D.B. (2000). Effective Project Management. Second Edition. Wiley Computer Publishing, New York.

Yasin, H Nazarkhan. (2004). Mengenal Klaim Konstruksi \& Penyelesaian Sengketa Konstruksi. Penerbit PT. GRAMEDIA PUSTAKA UTAMA. Jakarta.

Yenri, Nofri., Zaidir dan Wardi. (2014). Analisis Faktor-Faktor yang Mempengaruhi Kinerja Mutu Proyek Jalan Perkerasan Lentur di Kabupaten Pasaman Barat (Studi Kasus: PT. X). Jurnal Penelitian Program Pasca Sarjana. Universitas Bung Hatta.

Mulyono, A.T. (2012). Disertasi Model Monitoring dan Evaluasi Pemberlakuan Standar Mutu Perkerasan Jalan Berbasis Pendekatan Sistemik, UGM. 